\title{
Endocrine Disruptors in Aquatic Environment: Effects and Consequences on the Biodiversity of Fish and
}

\section{Amphibian Species}

Ana Paula Alves da Silva, Cícero Diogo Lins de Oliveira, Ana Maria Siqueira Quirino, Francisco Danilo Morais da Silva, Rogério de Aquino Saraiva

Universidade Federal Rural de Pernambuco/Unidade Acadêmica de Serra Talhada. Programa de Pós-graduação em Biodiversidade e Conservação. Avenida Gregório Ferraz Nogueira, S/N,

Bairro: José Tomé de Souza Ramos, CEP: 56909-535, Serra Talhada, Pernambuco, Brasil.

\section{Jacqueline Santos Silva-Cavalcanti}

Universidade Federal Rural de Pernambuco (UFRPE). Bairro Dois Irmãos, Recife, Pernambuco, Brasil

Received: December 18, 2017 Accepted: January 5, 2018 Published: January 30, 2018

doi:10.5296/ast.v6i1.12565 URL: https://doi.org/10.5296/ast.v6i1.12565

\begin{abstract}
Endocrine Disruptors (EDs) are synthetic or natural chemical compounds of exogenous origin that can cause serious health damage, in the growth and reproduction of animals when released into the aquatic environment through anthropic activities. Taking into account the current impact of pollutants on aquatic biodiversity in the last years, this study aims to systematically review the relevant literature on currently known EDs, focusing on their sources, their effects, and consequences on the aquatic biota, with emphasis to fish and amphibians. About $70 \%$ of the analyzed studies report that sewage represents the major source of EDs contamination to the water environment, and more than $90 \%$ of these contaminants are associated with interference in the sexual differentiation of aquatic animals, infertility, and reduction of sperm production. In addition, the main effects caused by EDs in fish include abnormalities in the reproductive system of animals (47\%), induction of vitellogenin (VTG) synthesis (20\%) and mortality of the species (13\%). In amphibians, the main effects caused by EDs include changes in hormonal activity (physiological functions) during the embryonic development (11\%), causing changes in anatomy (33\%) and behavior $(11 \%)$, leading to a reduction in reproductive success (11\%), as well as gonadal abnormalities (22\%), hermaphroditism (33\%) and other alterations in the reproductive system (45\%). Finally, this report calls attention to the importance to the rational use of these substances, as well as to encourage scientific research that shows the real seriousness of these
\end{abstract}


contaminations on the decline of fish and amphibian populations, showing mediating and mitigating solutions to their impacts.

Keywords: endocrine disruption, hormonal changes, pollutants, aquatic biota, aquatic ecotoxicology

\section{Introduction}

The compounds that pose a risk to the proper functioning of the endocrine system include endocrine modulators and endocrine disruptors (EDs) (Lyche et al., 2013). In endocrine modulation, the clinical symptoms observed in individuals are milder and reversible, while the effects of endocrine disruptors are more serious and not Always reversible, and may lead to death (Moraes et al., 2008). In this case, EDs are synthetic or natural chemical compounds of exogenous origin, which can not only cause damage to health but can also affect animal growth and reproduction (Reis Filho et al., 2007; Moraes et al., 2008).

Drugs, synthetic hormones, natural steroids, chemical industrial products, pesticides, fire retardants, perfluorinated compounds, among others, are examples of EDs due to their characteristic deleterious effects. Furthermore, some of them are also considered to be Persistent Organic Pollutants (POPs) for the reason that they are resistant to environmental degradation through biological, chemical, and/or photolytic processes (Bila and Dezotti, 2007; Reis Filho et al., 2007; Loutchanwoot et al., 2013; Lyche et al., 2013).

Although EDs have been studied for some time, attention has been currently focused on these substances due to new findings on the severity and variety of damages that they can cause to human and animal health as well as biodiversity impairment (Meyer et al., 1999; Lee et al., 2015). Effects such as, for example, interference on the animals' sexual differentiation, resulting in the feminization of males or vice versa, besides damage to their fertility (Moraes et al., 2008; Biancardi et al., 2012). In cases of animals exposed to EDs where the effects are not so intense as to make them infertile, disturbances can be observed to their offspring or to other individuals in the population (Lyche et al., 2013). In addition, some EDs may function as cancer inducers (Bila and Dezotti, 2007).

Therefore, EDs can interfere with the organisms' metabolic pathways due to the similarity between their chemical structure and that of endogenous hormones. It can manifest their action at different points of hormonal functioning, ranging from the production of hormones to its excretion and biotransformation, enabling the triggering of adverse responses and alteration of cellular function (Confort and Silva, 2013).

Consequently, these substances bind to one or more types of cellular receptors (e.g., in sexual reversal, there may be involvement of the estrogen receptor) and elicit agonist or antagonistic responses (Crain et al., 2000). Thus, because they possess a chemical similarity with endogenous hormones, EDs can associate with the proteins that carry the hormones, altering hormonal metabolism and, subsequently, deregulating the endocrine system (Moraes et al., 2008).

Some of these compounds that act as EDs are called persistent organochlorine pesticides and 
are known to resist chemical, physical, biological and photochemical degradation. They undergo slow degradation and persist in the environment for long periods of time, which leads to the compromise of whole food chains through trophic magnification. In addition, some EDs are lipophilic compounds, which can accumulate in the adipose tissue of animals, persisting in organisms for many years (Mrema et al., 2013). Even at very low doses, some EDs may have deleterious effects on exposed organisms (Bila and Dezotti, 2007).

One of the most studied EDs is dichlorodiphenyltrichloroethane (DDT), which was already heavily used as an insecticide in the second half of the 20th century, but is now banned in many countries. One of the metabolites of DDT, p, p'- dichlorodiphenyldichlorethylene (DDE), is commonly found in human body fluids and has a negative effect on chromosome integrity of human spermatozoa in in vitro experiments (Tavares et al., 2013).

There are reports about the feminization of the reproductive tract of male fish of the species (Rutilus rutilus Linnaeus, 1758) found in rivers of the United Kingdom. It has been shown that this feminization was related to the presence of estrogenic compounds that were released into rivers through domestic sewage, and that the EDs effects were irreversible (Rodgers-Gray et al., 2001). In another study, it was reported that exposure of zebrafish females (Danio rerio Hamilton, 1822) to POPs had a suppressive effect on ovarian follicle development. There was not only a decrease in egg production compared to control females but also decreased the viability of eggs produced (Lyche et al., 2013).

The main objective of this study is to present the main EDs existing in the aquatic environment, and their main consequences in the aquatic biota, with emphasis on fish and amphibians, as well as emphasize worldwide research on this subject. Reviews like this are important because can facilitate the conservation efforts and give power to the protection and management strategies. This study can be used both in general ecological and management perspective.

\section{Material and Methods}

The research is based on a systematic review, which is a type of research with a well- defined question, aiming to identify, select, evaluate and synthesize the available relevant evidence (Galvão and Pereira, 2014). Hence, we present in this study the main approaches discussed by other authors (between 1990-2017) who worked with Endocrine Disruptors (EDs) problem in relation to the aquatic biota of fish and amphibians.

In this case, according to Galvão and Pereira (2014), the work in question predicted the following steps: (1) elaboration of the research question ("What are the main effects of endocrine disruptors on aquatic biota with an emphasis on fish and amphibians?"); (2) literature search; (3) selection of articles; (4) data extraction; (5) methodological quality assessment; (6) data synthesis (meta-analysis); (7) evaluation of evidence quality; and (8) writing and publication of results.

To conduct this systematic review, we used the following electronic research databases: Scopus ${ }^{\circledR}$, Google ${ }^{\circledR}$ Scholar, PUBMED ${ }^{\circledR}$ and Science Direct ${ }^{\circledR}$, with the combination of proper keywords during the search ("endocrine disruptors" and "aquatic environment"; "endocrine 
disruptors" and "fish"; "endocrine disruptors" and "amphibian"). Here, over 67 articles spanning the last 30 years are reviewed with following objectives: (i) to evaluate current EDs problems for aquatic biota (43 articles) and (ii) the effects of DEs to fish and amphibians biota (24 articles).

\section{Results and Discussion}

\subsection{Endocrine Disruptors in the Aquatic System}

Endocrine disruptors (EDs) are characterized as micropollutants (Muller et al., 2008), and are commonly discharged into the aquatic environment through anthropic activities (Abreumota et al., 2014; Venturini et al., 2015). In general, sewage represents the largest source of contamination of pollutants to the water environment (Cordeiro et al., 2008). This contamination causes serious public health problems and negative impacts on aquatic fauna and flora, besides inducing ecosystem imbalance (Pratt et al., 2008). Several substances have the characteristic of affecting the animals' endocrine system (Bila and Dezotti, 2007), and these endocrine disrupting substances have two classifications: (a) natural, produced by plants and animals (phytoestrogens and estrogens); or (b) synthetic, man-made substances used in the manufacture of oral contraceptives, in hormone replacement, as a feed additive in the diet of several animals (Ghiselli and Jardim, 2007), for use in industry and agriculture, socalled xenoestrogens (Behera et al., 2011). Some examples of synthetic substances are alkylphenols, pesticides, phthalates, polychlorinated biphenyls, bisphenol A and drugs (Table 1).

Table 1. List of substances classified as Endocrine Disruptors (EDs) and their main route of transmission.

$\begin{array}{ll}\begin{array}{l}\text { Substance/Chemical } \\ \text { Structure }\end{array} & \begin{array}{l}\text { Characteristics/ Path of Contamination } \\ \text { to the Water Bodies }\end{array} \\ \begin{array}{l}\text { Natural estrogen, related to the } \\ \text { development of female sexual } \\ \text { characteristics and reproduction, used for } \\ \text { the manufacture of oral contraceptives and } \\ \text { in cases of hormone replacement/excreted Ikehata et al., } \\ \text { in the feces and urine of (2006). } \\ \text { humans and/or inadequately dumped into } \\ \text { the environment (in the form of a drug), } \\ \text { arriving to water bodies through sewage } \\ \text { networks. }\end{array}\end{array}$

Estrone (E1)

Natural estrogen/excreted in the feces and Ikehata et al., urine of humans and/or dumped into the (2006). environment, reaching water bodies 
<smiles>CC12CCC3c4ccc(O)cc4CCC3C1CCC2=O</smiles>

Phthalates<smiles>CCCOC(=O)c1ccccc1C(=O)OCC</smiles>

DDT $\quad(2,2 \quad$ bis-p- Synthetic Substance, xenoestrogen, used as chlorophenyl -1,1,1- a pesticide in agriculture/contaminate trichloroethane)<smiles>Clc1ccc(C(c2ccc(Cl)cc2)C(Cl)(Cl)Cl)cc1</smiles>

$17 \alpha$-Ethinylestradiol (EE2)<smiles>C#CC1(O)CC2C3CCc4cc(O)ccc4C3CCC21C</smiles>

Estriol (E3)

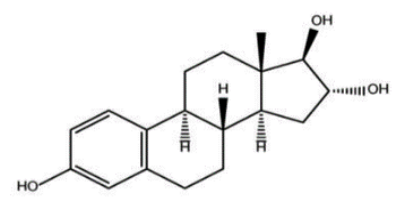

Diethylstilbestrol
Synthetic Substance, xenoestrogen, compounds with oxygen, generated Ghiselli and through industrial activity/reach the water Jardim (2007); bodies through inappropriate disposal of Bila and industrial solid waste and through sewage Dezotti (2007); networks.

Reis Filho et al. (2006).

Ghiselli and Jardim (2007); Bila and Dezotti (2007); Reis Filho et al. (2006).

Synthetic estrogen, used as contraceptive/ are found in surface water through inappropriate disposal of drugs in the natural environment and excreted through urine and feces.

Bila and Dezotti, (2007).

Bila and

Dezotti, (2007). Natural estrogen/excreted through urine and feces, being released into the sewer. 
<smiles>CCC(=C(CC)c1ccc(O)cc1)c1ccc(O)cc1</smiles>

Bisphenol A (BPA) Xenoestrogen, produced by industry, widely found in the environment/reach<smiles>CC(C)(c1ccc(O)cc1)c1ccc(O)cc1</smiles>
water bodies through the inappropriate disposal of industrial solid waste and also Aquino et al., (2013). through sewage networks.

Xenoestrogen, produced by industry, widely found in the environment/reach<smiles>CCCC(C)C(c1ccc(O)cc1)C(C)C</smiles>
water bodies through the inappropriate disposal of industrial solid waste and also through sewage networks.

Aquino et al., (2013).

Urban effluents are considered the main form of entry of EDs into water bodies and are normally discarded in the environment through excretion of humans and other animals (Diniz et al., 2010), of untreated sewage or with primary treatment in bodies of water (Sodré et al., 2010) and the inadequate disposal of drug residues in dumpsites and landfills. These drugs contain resistant EDs molecules, and when excreted in the urine, feces and/or in the original form are difficult to eliminate and may persist in the environment (D'Ascenzo et al., 2003).

As well as urban effluents, effluents generated by industry (plastic manufacturing) and agricultural activities (livestock confinement, use of animal manure and sludge from sewage treatment plants such as compost and soil fertilizer, and the use of hormones such as food supplements in livestock and aquaculture) (Orlando et al., 2004; Young et al., 2004), are also considered important pathways of EDs contamination in the aquatic environment (Kuster et al., 2004, Orlando et al., 2004) (Figure 1). 


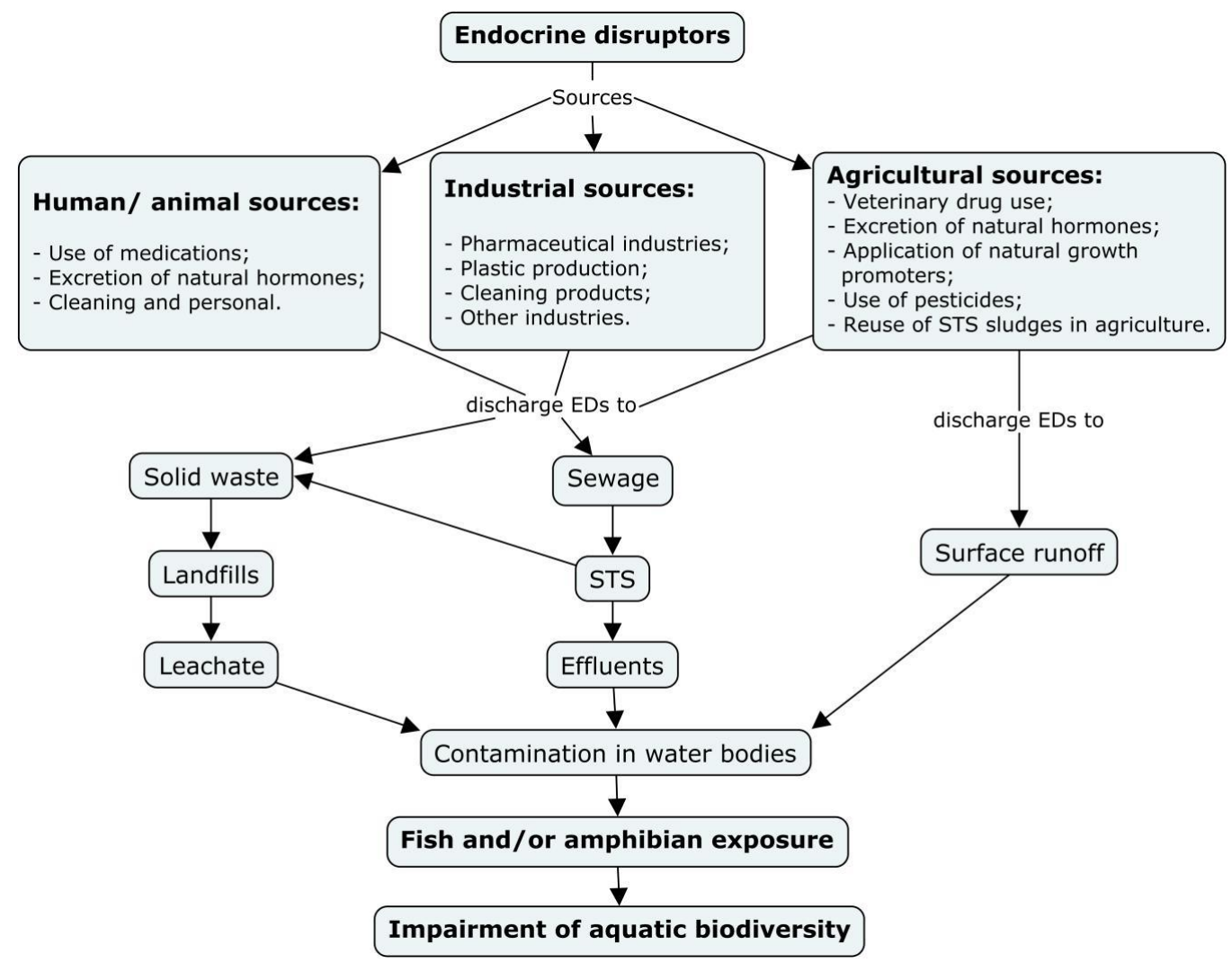

Figure 1: Routes of contamination of water bodies and exposure of fish and/or amphibian to substances characterized as endocrine disruptors (STS = Sewage Treatment Station; EDs = Endocrine disruptors) (Adapted from Aquino et al., 2013).

Among the synthetic substances, pesticides are classified as being the largest group of EDs. Traces of various pesticides have been found in bodies of water, soil and food, which can cause drastic changes in the diversity and dynamics of various aquatic animals, as well as causing serious damage to humans (Bila and Dezotti, 2007).

\subsection{Effects of Endocrine Disrupters in Fish}

The effects of EDs on the environment depend not only on their concentrations but also on other factors, such as lipophilicity, persistence, bioaccumulation, exposure time, biotransformation and excretion mechanisms (Bila and Dezotti, 2007). Due to these factors, fish become one of the animals most directly affected by these contaminants. The aquatic risk caused by EDs can lead to changes in the community, reducing the most sensitive species and increasing the most resistant, with the consequent loss of biodiversity (Palma et al., 2014).

The main effects caused by endocrine disrupters have been reported in fish, including abnormalities in the reproductive system of animals, induction of vitellogenin (VTG) synthesis in fish plasma and effects on human health, such as reduction in sperm production and increase of the incidence of some types of cancer (Bila and Dezotti, 2007). According to the European Union (EU), endocrine disrupters can: directly damage and change the function of an endocrine organ; interact with a receptor for hormones or, change the metabolism of a 
hormone in an endocrine organ.

Among the main sources, domestic effluents are sources of estrogenic substances in the aquatic environment. Research has shown that $17 \beta$-estradiol natural estrogens together with $17 \alpha$-ethinylestradiol are responsible for most of the estrogenic activity detected, these substances are excreted in the sewage and, most of them are not treated or are not completely removed in the treatment plant, followed by surfactants of nonylphenol polyethoxylates (NPEOx) and nonylphenol (NP) as the main degradation product (Solé et al., 2000; Reis Filho et al., 2007; Bila and Dezotti, 2007).

The major contaminants and consequences of ED in fish are summarized in Table 2. The production of fertile eggs of Pomatoschistus minutus (Pallas, 1770) was reduced by 90\%

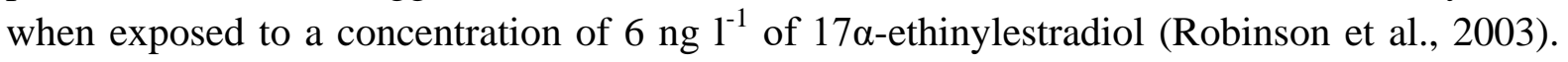
On the other hand, Thorpe et al. (2003) in an experiment with juvenile zebrafish, Danio rerio (Hamilton, 1822), exposed to concentrations of $100 \mathrm{ng} / \mathrm{L}$ of $17 \beta$-estradiol, for a period of 21 days, detected reproductive damages such as feminization of the reproductive tube, thus showing how much damage, these hormones can do to fish.

Table 2. Types of contaminants, fish species, consequences, type of environment and place of study of reviewed works.

\begin{tabular}{|c|c|c|c|c|c|}
\hline Contaminant & Species & Effects & $\begin{array}{l}\text { Type of } \\
\text { environment }\end{array}$ & $\begin{array}{l}\text { Place } \\
\text { study }\end{array}$ & Author \\
\hline 17/-estradiol & $\begin{array}{l}\text { Oryzias latipes } \\
\text { (Temminck } \\
\text { Schlegel 1846) }\end{array}$ & Hermaphroditism & Marine & USA & $\begin{array}{l}\text { Hartley et } \\
\text { al., 1998. }\end{array}$ \\
\hline Metais pesados & $\begin{array}{l}\text { Oncorhynchus mykiss } \\
\text { (Walbaum, 1792) }\end{array}$ & $\begin{array}{l}\text { Disorders of } \\
\text { cortisol synthesis }\end{array}$ & River & Canada & $\begin{array}{l}\text { Leblond etb } \\
\text { al., } 1999 .\end{array}$ \\
\hline 17ß-estradiol & $\begin{array}{l}\text { Cyprinodon variegatus } \\
\text { (Lacepède, 1803) }\end{array}$ & $\begin{array}{l}\text { Induction of VTG } \\
\text { synthesis in blood }\end{array}$ & Marine & USA & $\begin{array}{l}\text { Folmar et al., } \\
2000 .\end{array}$ \\
\hline 17/-estradiol & $\begin{array}{l}\text { Pimephales promelas } \\
\text { (Rafinesque, 1820) }\end{array}$ & $\begin{array}{l}\text { Changes in gonad } \\
\text { weight }\end{array}$ & River & $\begin{array}{l}\text { United } \\
\text { Kingdom }\end{array}$ & $\begin{array}{l}\text { Panter et al., } \\
2000 \text {. }\end{array}$ \\
\hline $\begin{array}{l}\text { Nonilfenol } \\
\text { polietoxilado } \\
\text { nonilfenol }\end{array}$ & $\begin{array}{l}\text { Cyprinus carpio } \\
\text { (Linnaeus, 1758) }\end{array}$ & $\begin{array}{l}\text { Induction of VTG } \\
\text { synthesis }\end{array}$ & River & Spain & $\begin{array}{l}\text { Solé et al., } \\
2000 \text {. }\end{array}$ \\
\hline Octilfenol & $\begin{array}{lr}\text { Oryzias } & \text { latipes } \\
\text { (Temminck } & \& \\
\text { Schlegel 1846) } & \end{array}$ & $\begin{array}{l}\text { Reproductive } \\
\text { effects }\end{array}$ & Marine & Germany & $\begin{array}{l}\text { Knörr e } \\
\text { Braunbeck, } \\
2002 .\end{array}$ \\
\hline 17a-etinil sintético & $\begin{array}{l}\text { Pomatoschistus } \\
\text { minutus } \\
\text { (Pallas, 1770) }\end{array}$ & $\begin{array}{l}\text { Late maturation, } \\
\text { and low egg } \\
\text { fecundity }\end{array}$ & Estuary & $\begin{array}{l}\text { United } \\
\text { Kingdom }\end{array}$ & $\begin{array}{l}\text { Robinson et } \\
\text { al., } 2002 \text {. }\end{array}$ \\
\hline 17a-etinilestradiol & $\begin{array}{l}\text { Pimephales promelas } \\
\text { (Rafinesque, 1820) }\end{array}$ & $\begin{array}{l}\text { Mortality of the } \\
\text { species }\end{array}$ & River & Switzerland & $\begin{array}{l}\text { Schmid et } \\
\text { al., 2002. }\end{array}$ \\
\hline 17ß-estradiol & $\begin{array}{l}\text { Danio rerio } \\
\text { (Hamilton, 1822) }\end{array}$ & $\begin{array}{l}\text { Feminization of the } \\
\text { reproductive tube }\end{array}$ & River & $\begin{array}{l}\text { United } \\
\text { Kingdom }\end{array}$ & $\begin{array}{l}\text { Thorpe et al., } \\
2003 \text {. }\end{array}$ \\
\hline Metais pesados & $\begin{array}{l}\text { Xiphias gladius } \\
\text { (Linnaeus, 1758) }\end{array}$ & $\begin{array}{l}\text { Induction of VTG } \\
\text { synthesis }\end{array}$ & Marine & Italy & $\begin{array}{l}\text { Fossi et al., } \\
2004 \text {. }\end{array}$ \\
\hline
\end{tabular}


$17 \alpha$-etinilestradiol

Monocrotofós profenofos

Pesticidas organoclorados esteroides

Nonilfenol

$17 \beta$-estradiol
Pimephales promelas (Linnaeus 1757)

e

Oreochromis niloticus (Linnaeus 1757)

Oreochromis niloticus

e (Linnaeus 1757)

Zacco ornitorrinco (Temminck Schlegel, 1846)

Betta splendens (Regan, 1910)
Changes reproductive behavior

Mortality of the River species

Thyroid disorder

River

Decreased \& reproduction

Change in mating River behavior
2018, Vol. 6, No. 1

USA

Salierno e

Kane, 2009.

Camarões Vroumsia et al., 2014.

Duarte e Borges, 2015.

Taiwan Lee et al., 2015.

Brazil Santos et al., 2016.

The toxicity of fipronil in fish varies by species (Pan-Uk, 2007). In a study carried out by Pan-Uk (2007), this substance is highly toxic to Lepomis macrochirus (Rafinesque, 1819) when it reaches an $\mathrm{LC}_{50}$ (Median Lethal Concentration) of $85 \mu \mathrm{g} / \mathrm{L}$ and Oreochromis niloticus (Linnaeus, 1757) reaching of $42 \mu \mathrm{g} / \mathrm{L}$, and less toxic to Oncorhynchus mykiss (Walbaum, 1792) and Cyprinus carpio (Linnaeus, 1758), which became toxic only at concentrations of 248 and $430 \mu \mathrm{g} / \mathrm{L}$, respectively. In the larval stage of Oncorhynchus mykiss exposed to concentrations higher than $6.6 \mu \mathrm{g} / \mathrm{L}$, it affects the growth of the species.

Heavy metals are important EDs, in the research conducted by Fossi et al. (2004), to know the effects of organochlorines and heavy metals $(\mathrm{Hg}, \mathrm{Cd}$, and $\mathrm{Pb})$ on swordfish specimens, they analyzed vitellogenin (VTG) and zone radiate proteins (ZRP). In this research, we found that VTG and ZRP were dramatically induced in some adult male specimens. Levels of heavy metals in the liver were in the following ranges: $\mathrm{Hg} \mathrm{1-22,} \mathrm{Cd} \mathrm{1-28}$ and $\mathrm{Pb} 0-1.6 \mathrm{ppm}$, indicating potential reproductive changes in these fish.

Research has been carried out with the intention of detecting EDs in the environment, in which those with interaction with the aquatic environment are highlighted. It is observed that a great effort has been made, mainly by more developed countries and that has many factories and chemical industries, to determine which substances can be classified as EDs and what their consequences are, whether for biota or environmental health.

\subsection{Effects of Endocrine Disrupters in Anuran Amphibians}

Hayes and coworkers (2003) showed that exposure to endocrine disrupting chemicals (EDCs) changes hormonal activity (physiological functions) during embryonic development and is responsible for changes in the anatomy, behavior and reproductive system of amphibians.

Agrochemicals or pesticides used in agriculture are associated with the population decline of anurans (Davidson and Knapp, 2007), as well as in gonadal abnormalities, hermaphroditism, changes in reproductive organs, among others (Hayes et al., 2002; McCoy et al., 2008).

In the study conducted by McCoy et al. (2008), the testicular function of anuran amphibians inhabiting environments contaminated with pesticides was compromised. In addition, there 
was a change in the life cycle of anurans, leading to reproductive abnormalities and consequently to population decline.

Atrazine $^{\circledR}$ is an endocrine disruptor that has rarely been studied in amphibians. Its effect on Xenopus laevis (Daudin, 1802) was the loss of male characteristics, such as the feminized larynx development, reduction of testosterone, reduction of sperm production, drop in fertility and reduction of reproductive glands in species exposed (Hayes et al., 2002). McCoy et al. (2008) evaluated the activity and reproductive success of anurans correlating with steroid concentrations (17 $\beta$-estradiol) and secondary sexual traits (Testosterona). Consequently, reproductive success in populations of anurans exposed to these agents would be reduced due to the reproductive abnormalities brought to them.

Heavy metals are a type of EDs studied for causing infertility and congenital malformation in fish and amphibians, especially cadmium that can be found easily in batteries, pesticides, galvanizing, pigment production and the processing of rubbers discarded in domestic and industrial waste or aquatic ecosystems (Lee et al., 2010).

The release of household effluents directly into the water bodies without previous treatment contains large amounts of 17 $\alpha$-ethinylestradiol (Hoffmann and Kloas, 2012) and Flutamide (antiandrogenic drugs) (Gregório, 2015) excreted by humans that may interfere with male sex hormones of anurans, in the secondary sexual characteristics, such as singing (Behrends et al., 2010) and the nuptial callus or sponge and serum levels of testosterone (Wyk et al., 2003).

As for the harmful effects of EDs on the analyzed taxa, according to Table 3 only two authors reported that there were no adverse effects on metamorphosis and sexual differentiation (Oka et al., 2008), and showed no morphological and histological changes in amphibian gonads (Murphy et al, 2006). Other studies (Hayes et al., 2002; Hayes et al., 2003; McCoy et al., 2008; Hoffmann and Kloas, 2012) found gonadal changes, hermaphroditism, and suggested that EDs are responsible for population decline in this group.

Table 3. Types of contaminants, frogs anuran species, consequences, type of environment and place of study of revised works.

\begin{tabular}{|c|c|c|c|c|c|c|}
\hline Contaminants & Species & Consequences & $\begin{array}{l}\text { Type } \\
\text { environments }\end{array}$ & of & Study site & Authors \\
\hline Atrazine & laevis (Daudin, & $\begin{array}{l}\text { Reduction of the size of the } \\
\text { larynx and hermaphroditism }\end{array}$ & $\begin{array}{l}\text { Terrestrial } \\
\text { aquatic }\end{array}$ & and & $\begin{array}{l}\text { Berkeley } \\
\text { and Nasco }\end{array}$ & $\begin{array}{l}\text { Hayes et } \\
\text { al., } 2002\end{array}$ \\
\hline Atrazine & $\begin{array}{l}\text { Rana pipiens (Schreber, } \\
1782)\end{array}$ & $\begin{array}{l}\text { Hermaphroditism and gonadal } \\
\text { abnormalities retarded }\end{array}$ & $\begin{array}{l}\text { Terrestrial } \\
\text { aquatic }\end{array}$ & and & $\begin{array}{l}\text { United } \\
\text { States }\end{array}$ & $\begin{array}{l}\text { Hayes et } \\
\text { al., } 2003\end{array}$ \\
\hline Atrazine & $\begin{array}{l}R . \text { catesbeiana; } R \text {. pipiens e } \\
\text { Rana clamitans (Latreille, } \\
1801)\end{array}$ & $\begin{array}{l}\text { No morphological changes and } \\
\text { histological in gonads }\end{array}$ & $\begin{array}{l}\text { Terrestrial } \\
\text { aquatic }\end{array}$ & and & $\begin{array}{l}\text { Michigan, } \\
\text { Kalamazoo }\end{array}$ & $\begin{array}{l}\text { Murphy et } \\
\text { al, } 2006\end{array}$ \\
\hline $\begin{array}{l}\text { Pesticidas } \\
\text { Testosterona } \\
\text { 17ß-estradiol }\end{array}$ & marinus (Linnaeus, & $\begin{array}{l}\text { Hermaphroditism and gonadal } \\
\text { abnormalities }\end{array}$ & $\begin{array}{l}\text { Terrestrial } \\
\text { aquatic }\end{array}$ & and & Flórida & $\begin{array}{l}\text { McCoy et } \\
\text { al., } 2008\end{array}$ \\
\hline Atrazine & laevis (Daudin, & $\begin{array}{l}\text { No adverse effects } \quad \text { on } \\
\text { metamorphosis and sexual } \\
\text { differentiation }\end{array}$ & Artificial & & $\begin{array}{l}\text { Hiroshima, } \\
\text { Japan }\end{array}$ & $\begin{array}{l}\text { Oka et al., } \\
2008\end{array}$ \\
\hline $\begin{array}{l}\text { Cadmium } \\
17 \beta \text {-estradiol }\end{array}$ & $\begin{array}{l}\text { Rana catesbeiana (Shaw, } \\
\text { 1802) }\end{array}$ & $\begin{array}{l}\text { Oxidative stress in hepatocytes } \\
\text { and } \\
\text { vitellogenin in males }\end{array}$ & $\begin{array}{l}\text { Terrestrial } \\
\text { aquatic }\end{array}$ & and & Japan & $\begin{array}{l}\text { Lee, et al., } \\
2010\end{array}$ \\
\hline $17 \alpha$-ethinylestradiol & $\begin{array}{l}\text { Xenopus } \\
1802)\end{array}$ & $\begin{array}{l}\text { Changes in mating behavior and } \\
\text { reducing reproductive success }\end{array}$ & Freshwater & & $\begin{array}{l}\text { Berlin, } \\
\text { Germany }\end{array}$ & $\begin{array}{l}\text { Hoffmann } \\
\text { e Kloas, } \\
2012\end{array}$ \\
\hline
\end{tabular}




\begin{tabular}{|c|c|c|c|c|c|}
\hline $17 \beta$-estradiol & $\begin{array}{l}\text { Rhinella schneideri (Werner, } \\
\text { 1894) }\end{array}$ & $\begin{array}{l}\text { Changes in espermatogêneses, } \\
\text { Oogenesis Bidderiana, and } \\
\text { responsiveness of hepatic } \\
\text { pigments }\end{array}$ & $\begin{array}{l}\text { Terrestrial and } \\
\text { Aquatic }\end{array}$ & $\begin{array}{l}\text { São José do } \\
\text { Rio Preto, } \\
\text { Brazil }\end{array}$ & $\begin{array}{l}\text { Freitas, } \\
2013\end{array}$ \\
\hline Flutamide & $\begin{array}{l}\text { Rhinella schneideri (Werner, } \\
\text { 1894) }\end{array}$ & $\begin{array}{l}\text { Increase of espermatogônias, } \\
\text { reduction of sperm, interference } \\
\text { in the morphology of the } \\
\text { reproductive organs and the liver }\end{array}$ & $\begin{array}{l}\text { Terrestrial, aquatic } \\
\text { and artificial }\end{array}$ & $\begin{array}{l}\text { São José do } \\
\text { Rio Preto, } \\
\text { Talhado and } \\
\text { Mirassol, } \\
\text { Brazil }\end{array}$ & $\begin{array}{l}\text { Gregório, } \\
2015\end{array}$ \\
\hline
\end{tabular}

The variety of reproductive modes and parental care is a notable feature in amphibians (Duellman and Trueb, 1994; Haddad, 1991) that are derived from morphological, physiological and behavioral characteristics (Pombal Júnior and Haddad, 2005). These taxa are considered important environmental indicators because they control some populations of vertebrates and invertebrates (Pough et al., 2003), and are excellent indicators of environments preserved and/or strongly changed by anthropic activity. Endocrine disruptors are one of the main aspects responsible for the reduction of populational density or even extinction (Silvano and Segala, 2007), hermaphroditism (Hayes et al., 2003; McCoy et al., 2008), changes in the reproductive behavior (Hoffmann and Kloas, 2012), changes in the histology and morphology of reproductive gonads (Hayes et al., 2003; McCoy et al., 2008; Freitas, 2013; Gregório, 2015).

\section{Concluding Remarks}

A large number of these substances, in addition to technical requirements and costs to measure them in organisms and in the environment, makes it difficult to determine the actual concentration of these elements and quantification of harm to the organisms. Consequently, investments in further studies are needed to uncover the real effects of these contaminants in the food chain, especially on the impacts of EDs on human health.

It is known that developing organisms exposed to EDs may undergo changes in sexual differentiation, leading to the feminization of males and vice versa. Adult individuals, on the other hand, may suffer damage to fertility such as loss of semen quality or reduced development of ovarian follicles. Also, due to biomagnification, humans and other animals can be targeted by these EDs indirectly, either through the contaminated waters or through the trophic chain.

It is therefore increasingly important to study EDs and to make decisions about them, as they can cause serious damage to the environment and wildlife through contamination of bodies of water, as well as human health. In addition, water is one of the main vehicles for the spread of toxic substances, such as agricultural pesticides. Even communities that are geographically distant from the sites of use of these substances are also affected by them, and it is important to realize that, when contamination occurs in a collection of water bodies, an entire food chain may be compromised.

\section{Acknowledgement}


The authors are grateful to Foundation for Support of Science and Technology of the State of Pernambuco (FACEPE-Brazil), Brazilian National Research Council (CNPq-Brazil), and to Coordenação de Amparo à Pesquisa no Ensino Superior (CAPES-Brazil), for providing support during the development of this work

\section{References}

Abreu-Mota, M. A., Moura, C. A. B., Bicego, M. C., Martins, C. C. (2014). Sedimentary biomarkers along a contamination gradient in a human-impacted sub-estuary in Southern Brazil: a multi-parameter approach based on spatial and seasonal variability. Chemosphere, 103, 156-163. http://dx.doi.org/10.1016/j.chemosphere.2013.11.052.

Aquino, S. F., Brandt, E. M. F., Chernichro, C. A. L. (2013). Remoção de fármacos e desreguladores endócrinos em estações de tratamento de esgoto: revisão da literatura. Engenharia Sanitária e Ambiental, 18, 187-204.

Behera, S. K., Kim, H. W., Jeong-Eun, O. H., Hung-Suck, P. (2011). Occurrence and removal of antibiotics, hormones and several other pharmaceuticals in wasterwater treatment plants of the largest industrial city of Korea. Science of the total environmental, 409, 4351-4360. http://dx.doi.org/10.1016/j.scitotenv.2011.07.015.

Behrends, T., Urbatzka, R., Krackow, S., Elepfandt, A., Kloas, W. (2010). Mate calling behavior of male South African clawed frogs (Xenopus laevis) is suppressed by the antiandrogenic endocrine disrupting compound flutamide. General and Comparative Endocrinology, 168, 269-274. http://dx.doi.org/10.1016/j.ygcen.2010.01.017.

Biancardi, M. F, Perez, A. P., Góes, R. M., Santos, F. C., Vilamaior, P. S., Taboga, S. R. (2012). Prenatal testosterone exposure as a model for the study of endocrine-disrupting chemicals on the gerbil prostate. Experimental Biology and Medicine, 237, 1298-1309. https://doi.org/10.1258/ebm.2012.012051.

Bila, D. M., Dezotti, M. (2003). Fármacos no Meio Ambiente. Química Nova, 26, 523-530.

Bila, D. M., Dezotti, M. (2007). Desreguladores endócrinos no meio ambiente: efeitos e consequências. Química nova, 30, 651-666.

Confort, V. A., Silva, M. C. (2013). Endocrine disruptors. Enciclopédia Biosfera, 9(17), 1098-1111.

Cordeiro, L. G. S. M., Carreira, R. S., Wagener, A. L. R. (2008). Geochemistry of fecal sterols in a contaminated estuary in southeastern Brazil. Organic Geochemistry, 39, 1097-1103. http://dx.doi.org/10.1016/j.orggeochem.2008.02.022.

Crain, D. A., Rooney, A. A., Orlando, E. F., Guillette. L. J. R. (2000). Endocrine disrupting contaminants and hormone dynamics: lessons from wildlife. In: GUILLETTE, L. J. JR; CRAIN, D. A. (Eds.). Environmental endocrine disrupters: an evolutionary perspective, 1-21.

D'Ascenzo, G., Corcia, A., Gentili, A., Mancini, R., Mastropasqua, R., Nazzari, M., Samperi, R. (2003). Fate of natural estrogen conjugates in municipal sewage transport and treatment facilities. Science of the Total Environment, 302, 199-209. http://dx.doi.org/10.1016/S0048-9697(02)00342-X.

Davidson, C., Knapp, R. A. (2007). Multiple stressors and amphibian declines: dual impacts of pesticides and fish on yellow legged frogs. Ecological Applications, 17, 587-597. 
http://dx.doi.org/10.1890/06-0181.

Diniz, M. S., Maurício, R., Petrovic, M., Alda, M. J. L., Amaral, L., Peres, I., Barceló, D., Santana, F. (2010). Assessing the estrogenic potency in a Portuguese wastewater treatment plant using an integrated approach. Journal of Environmental Sciences, 22, 1613-1622. https://doi.org/10.1016/S1001-0742(09)60297-7.

Duarte, A. C. R., Borges, J. C. S. (2016). Resultados preliminares do efeito da água da represa Billings na tireóide das tilápias. Atas de Saúde Ambiental-ASA, 3(2), 10-16.

Duellman, W. E., Trueb, L. (1994). Biology of amphibians. New York: The Johns Hopkins University Press, 670p.

European Workshop on Endocrine Disrupters. (2001). European ED workshop, Aronsborg (Balsa) Sweden.

Folmar, L. C., Hemmer, M., Hemmer, R., Bowman, C., Kroll, K., Denslow, N. D. (2000). Comparative estrogenicity of estradiol, ethynyl estradiol and diethylstilbestrol in an in vivo, male sheepshead minnow (Cyprinodon variegatus), vitellogenin bioassay. Aquatic Toxicology, 49, 77-88. http://dx.doi.org/10.1016/S0166-445X(99)00076-4.

Fossi, M. C., Casini, S., Marsili, L., Ancora, S., Mori, G., Neri, G., Romeo,T., Ausili, A. (2004). Evaluation of ecotoxicological effects of endocrine disrupters during a four-year survey of the Mediterranean population of swordfish (Xiphias gladius). Marine environmental research, 58, 425-429. http://dx.doi.org/10.1016/j.marenvres.2004.03.026.

Freitas, J. S. (2013). Efeito do hormônio 17ß-estradiol na gametogênese dos órgãos de Bidder e testículos e no tecido hepático em machos de Rhinella schneideri (Anura: Bufonidae). Programa de Pós- Graduação em Biologia Animal, do Instituto de Biociências, Letras e Ciências Exatas da Universidade Estadual Paulista "Júlio de Mesquita Filho", São José do Rio Preto, 150 f. : il.

Galvão, T. F., Pereira, M. G. (2014). Revisões sistemáticas da literatura: passos para sua

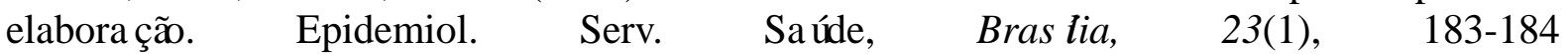
http://www.scielo.br/pdf/ress/v23n1/2237-9622-ress-23-01-00183.pdf

Gerhardt, T. E., Silveira, D. T. (2009). Métodos de pesquisa. Universidade Aberta do Brasil UAB/UFRGS. Porto Alegre: Editora da UFRGS.

Ghiselli, G., Jardim, W. F. (2007). Interferentes endócrinos no ambiente. Química Nova, 30, 695-706.

Gregório, L. S. (2015). Efeitos da Flutamida na morfologia dos órgãos reprodutivos e fígado de Rhinella schneideri (Anura: Bufonidae). Programa de Pós- Graduação em Biologia Animal, do Instituto de Biociências, Letras e Ciências Exatas da Universidade Estadual Paulista "Júlio de Mesquita Filho", São José do Rio Preto, 62 f.

Hartley, W. R., Thiyagarajah, A., Anderson, M. B., Broxson, M. W., Major, S. E., Zell, S. I. (1998). Gonadal development in Japanese medaka (Oryzias latipes) exposed to $17 \beta$-estradiol. Marine environmental research, 46, 145-148. https://doi.org/10.1016/S0141-1136(98)00007-5.

Hayes, T. B., Collins, A., Lee, M., Mendoza, M., Noriega, N., Stuart, A. A., Vonk, A. (2002). Hermaphroditic, demasculinized frogs after exposure to the herbicide atrazine at low ecologically relevant doses. Proceedings of the National Academy of Sciences, 99, 5476-5480. 
https://doi.org/10.1073/pnas.082121499.

Hayes, T., Haston, K., Tsui, M., Hoang, A., Haeffele, C., \& Vonk, A. (2003). Atrazine-Induced Hermaphroditism at $0.1 \mathrm{ppb}$ in American Leopard Frogs (Rana pipiens): Laboratory and Field Evidence. Environ Health Perspect, 111, 568-575.

Hoffmann, F., Kloas, W. (2012). Estrogens Can Disrupt Amphibian Mating Behavior. PLoS ONE, 7, 1-7. http://dx.doi.org/10.1371/journal.pone.0032097.

Ikehata, K., Naghashkar, N. J., El-Din, M. G. (2006). Degradation of Aqueous Pharmaceuticals by Ozonation and Advanced Oxidation Processes: A Review. Ozone Science e Engineering, 28, 353-414. http://dx.doi.org/10.1080/01919510600985937.

Knörr, S., Braunbeck, T. (2002). Decline in reproductive success, sex reversal, and developmental alterations in Japanese medaka (Oryzias latipes) after continuous exposure to octylphenol. Ecotoxicology and environmental safety, 51, 187-196. https://doi.org/10.1006/eesa.2001.2123.

Kuster, M., Azevedo, D. A., López de Alda, M. J., Aquino Neto, F. R., Barceló, D. (2009). Analysis of phytoestrogens, progestogens and estrogens in environmental Waters from Rio de Janeiro (Brazil). Environment International, 35, 997-1003. http://dx.doi.org/10.1016/j.envint.2009.04.006.

Kuster, M., López de Alda, M. J., Barceló, D. (2004). Analysis and distribution of estrogens and progestogens in sewage sludge, soils and sediments. Trends in Analytical Chemistry, 23, 790-798. http://dx.doi.org/10.1016/j.trac.2004.08.007.

Leblond, V. S., Hontela, A. (1999). Effects ofin VitroExposures to Cadmium, Mercury, Zinc, and 1-(2-Chlorophenyl)-1-(4-chlorophenyl)-2, 2-dichloroethane on Steroidogenesis by Dispersed Interrenal Cells of Rainbow Trout (Oncorhynchus mykiss). Toxicology and Applied Pharmacology, 157, 16-22. https://doi.org/10.1006/taap.1999.8660.

Lee, C. C., Jiang, L. Y., Kuo, Y. L., Chen, C. Y., Hsieh, C. Y., Hung, C. F., Tien, C. J. (2015). Characteristics of nonylphenol and bisphenol A accumulation by fish and implications for ecological and human health. Science of The Total Environment, 502, 417-425. http://doi.org/10.1016/j.scitotenv.2014.09.042.

Lee, K. W., Chang, Z., Oh, B. S., Lu, M., Park, J. S. (2010). Estrogenic Response in Male Bullfrog (Rana catesbeiana) Hepatocytes After Single or Combined Exposure to Cadmium (Cd) and 17beta-Estradiol (E2). Bull Environ Contam Toxicol, 85, 452-456. http://doi.org/10.1007/s00128-010-0119-5.

Loutchanwoot, P., Srivilai, P., Jarry, H. (2013). Effects of the natural endocrine disruptor equol on the pituitary function in adult male rats. Toxicology, 304, 69-75. http://doi.org/10.1016/j.tox.2012.11.017.

Lyche, J. L., Grześ, I. M., Karlsson, C., Nourizadeh-Lillabadi, R., Berg, V., Kristoffersen, A. B., Skåre, J. U., Alestrøm, P., Ropstad, E. (2013). Parental exposure to natural mixtures of POPs reduced embryo production and altered gene transcription in zebrafish embryos. Aquatic Toxicology, 126, 424-434. http://doi.org/10.1016/j.aquatox.2012.08.019.

Mccoy, K. A., Bortnick, L. J., Campbell, C. M., Hamlin, H. J., Guillette Jr, L. J., Mary, C. M. S. T. (2008). Agriculture Alters Gonadal Form and Function in the Toad Bufo marinus. Environmental Health Perspectives, 116, 1526- 1532. 
Meyer, A., Sarcinellli, P. N., Moreira, J. C. (1999). Estarão alguns grupos populacionais brasileiros sujeitos à ação de disruptores endócrinos. Cadernos de Saúde Pública, 15(4), 845-850. http://dx.doi.org/10.1590/S0102-311X1999000400018.

Moraes, N. V., Grando, M. D., Valerio, D. A. R., Oliveira, D. P. (2008). Exposição ambiental a desreguladores endócrinos: alterações na homeostase dos hormônios esteroidais e tireoideanos. Revista Brasileira de Toxicologia, 21, 1-8.

Mrema, E. J., Rubino, F. M., Brambilla, G., Moretto, A., Tsatsakis, A. M., Colosio, C. (2013). Persisten organochlorinated pesticides and mechanisms of their toxicity. Toxicology, 307, 74-88. http://doi.org/10.1016/j.tox.2012.11.015.

Muller, M., Rabenolina, F., Balaguer, P., Patureal, D., Lemenach, K., Budzinski, H., Barceló, D., López de Alda, M., Kuster, M., Delogenés, J. P., Hernandez-Raquet, G. (2008). Cheminal and Biological analysis of endocrine-disrupting hormones and estrogenic activity in an advanced sewage treatment plant. Environmental Toxicology And Chemistry, 27, 1649-1658. http://doi.org/10.1897/07-519.1.

Murphy, M. B., Hecker, M., Coady, K. K., Tompsett, A. R., Jones, P. D., Du Preez, L. H., Everson, G. J., Solomon, K. R., Carr, J. A., Smith, E. E, Kendall, R. J., Van Der Kraak, G., Giesy, J. P. (2006). Atrazine concentrations, gonadal gross morphology and histology in ranid frogs collected in Michigan agricultural áreas. Aquatic Toxicology, 76, 230-245. http://doi.org/10.1016/j.aquatox.2005.09.010.

Oka, T., Tooi, O., Mitsui, N., Miyahara, M., Ohnishi, Y., Takase, M., Kashiwagi, A., Shinkai, T., Santo, N., Iguchi, T. (2008). Effect of atrazine on metamorphosis and sexual differentiation in Xenopus laevi. Aquatic Toxicology, 87, 215-226. http://doi.org/10.1016/j.aquatox.2008.02.009.

Orlando, E. F., Kolok, A. S., Binzcik, G. A., Gates, J. L., Horton, M. K., Lambright, C. S., Gray, L. E., Soto, A. M., Guillette, L. J. (2004). Endocrine-disrupting effects of cattle feedlot effluent on an aquatic sentinel species, the fathead minnow. Environ. Health Persp. 112, 353-358.

Palma, P., Kock-Schulmeyer, M., Alvarenga, P., Ledo, L., Barbosa, I. R., Lopez De Alda, M. (2014). Risk assessment of pesticides detected in surface water of the Alqueva reservoir (Guadiana basin, southern of Portugal). Sci. Total Environ., 488-489, 208-219. http://doi.org/10.1016/j.scitotenv.2014.04.088.

Panter, G. H., Thompson, R. S., Sumpter, J. P. (1998). Adverse reproductive effects in male fathead minnows (Pimephales promelas) exposed to environmentally relevant concentrations of the natural oestrogens, oestradiol and oestrone. Aquatic Toxicology, 42, 243-253. http://doi.org/10.1016/S0166-445X(98)00038-1.

Pan-Uk. (2017). Disponível em: http://www.pan-uk.org/pestnews/actives/fipronil.htm. Acesso em 06 janeiro 2017.

Pombal, Jr., J. P., Haddad, C. F. B. (2005). Estratégias e modos reprodutivos de anuros (Amphibia) em uma poça permanente na Serra de Paranapiacaba, Sudeste do Brasil. Papéis Avulsos de Zoologia, Museu de Zoologia da Universidade de São Paulo, 45, 201-213.

Pough, F. H., Janis, C. M., Heiser, J. B. (2003). A vida dos vertebrados. São Paulo: Atheneu p. 261-269, 3. Ed., Cap. 9. 
Pratt, C., Warnken, J., Leeming, R., Arthur, M. J., Grige, D. I. (2008). Degradation and responses of coprostanol and selected sterol biomarkers in sediments to a simulated major sewage pollution event: A microcosm experiment under subtropical estuarine conditions. Organic Geochemistry, 39, 353-369. http://doi.org/10.1016/j.orggeochem.2007.06.009.

Reis Filho, R. W., Araújo, J. C., Vieira, E. M. (2006). Hormônios Sexuais Estrógenos: Contaminantes Bioativos. Química Nova. 29, 817-822.

Reis Filho, R. W., Barreiro, J. C., Vieira, E. M., Cass, Q. B. (2007). Fármacos, ETEs e corpos hídricos. Revista Ambi-Água, 2, 54-61.

Reis Filho, R. W., Luvizotto-Santos, R., Vieira, E. M. (2007). Poluentes emergentes como desreguladores endócrinos. Journal of the Brazilian Society of Ecotoxicology, 2, 283-288.

Rodgers-Gray, T. P., Jobling, S., Kelly, C., Morris, S., Brighty, G., Waldock, M. J., Sumpter, J. P., Tyler, C. R. (2001). Exposure of juvenile roach (Rutilus rutilus) to treated sewage effluent induces dose-dependent and persistent disruption in gonadal duct development. Environmental Science \& Technology, 35, 462-470. http://doi.org/10.1021/es001225c.

Robinson, C. D., Brown, E., Craft, J. A., Davies, I. M., Moffat, C. F., Pirie, D., Robertson, F., Stagg, R. M., Struthers, S. (2003). Effects of sewage effluent and ethynyl oestradiol upon molecular markers of oestrogenic exposure, maturation and reproductive success in the sand goby (Pomatoschistus minutus, Pallas). Aquatic Toxicology, 62, 119-134. http://doi.org/10.1016/S0166-445X(02)00079-6.

Salierno, J. D., Kane, A. S. (2009). 17 $\alpha$-Ethinylestradiol alters reproductive behaviors, circulating hormones, and sexual morphology in male fathead minnows (Pimephales promelas). Environmental Toxicology and Chemistry, 28, 953-961. http://doi.org/10.1897/08-111.1.

Santos, B. D., Silva, M. C. G., Santos, T. P., Silva, S. C. B. L., Cadena, M. R. S., Cadena, P. G. (2016). Efeitos de hormônios esteroides de contraceptivos orais combinados sobre os parâmetros comportamentais de Betta splendens (Regan, 1909). Arquivo brasileiro de medicina veterinária e zootecnia, 68, 387-396.

Schmid, T., Gonzalez-Valero, J., Rufli, H., Dietrich, D. R. (2002). Determination of vitellogenin kinetics in male fathead minnows (Pimephales promelas). Toxicology letters, 131, 65-74. http://doi.org/10.1016/S0378-4274(02)00043-7.

Silvano, D. L., Segalla, M. V. (2005). Conservação de anfíbios no Brasil. Megadiversidade, 1, 79-86.

Sodré, F. F., Locatelli, A. F., Jardim, W. F. (2010). Sistema Limpo Em Linha Para Extração Em Fase Solida De Contaminantes Emergentes Em Aguas Naturais. Química Nova, 33, 216-219. http://dx.doi.org/10.1590/S0100-40422010000100037.

Solé, M., López De Alda, M.J., Castillo, M., Porte, C., Ladegaard-Pedersen, K., Barceló, D. (2000). Estrogenicity determination in sewage treatment plants and surface waters from the Catalonian area (NE Spain). Environmental Science \& Technology, 34, 5076-5083. http://dx.doi.org/10.1021/es991335n.

Tavares, R. S., Mansell, S., Barratt, C. L. R., Wilson, S. M., Publicover, S. J., Ramalho-Santos, J. (2013). P,P'-DDE activates CatSper and compromises human sperm function at environmentally relevant concentrations. Human Reproduction, 1-11. 
https://doi.org/10.1093/humrep/det372.

Thorpe, K. L., Cummings, R. I., Hutchinson, M. S., Scholze, M., Brighty, G., Sumpter, J. P., Tyler, C. R. (2003). Relative potencies and combination effects of estrogens in fish. Environmental Science \& Technology, 37, 1142- 1149. https://doi.org/10.1021/es0201348.

Venturini, N., Bicego, M. C., Taniguchi, S., Sasaki, S. T., Garcia Rodriguez, F., Brugnoli, E., Muniz, P. (2015). A multi-molecular marker assessment of organic pollution in shore sediments from the Rio de la Plata Estuary, SW Atlantic. Marine pollution bulletin, 91, 461-475. http://doi.org/10.1016/j.marpolbul.2014.06.056.

Vroumsia, T., Moussa, D., Feudjio, C., Mmae, J. P. (2014). Acute toxicity of monocalm 400s1 (monocrotophos) and profenalm $720 \mathrm{ec}$ (profenofos) on Oreochromis niloticus (Linnaeus, $\begin{array}{llll}\text { 1758). Journal of Applied Biosciences, } & \text { 68, 6763-6770. }\end{array}$ http://dx.doi.org/10.4314/jab.v78i1.16.

Wyk, J. H., Pool, E. J., Leslie, A. J. (2003). The Effects of Anti-Androgenic and Estrogenic Disrupting Contaminants on Breeding Gland (Nuptial Pad) Morphology, Plasma Testosterone Levels, and Plasma Vitellogenin Levels in Male Xenopus laevis (African Clawed Frog). Archives of Evironmental Contamination and Toxicology, 44, 247-256. http://dx.doi.org/10.1007/s00244-002-1161-z.

Young, W. F., Whitehouse, P., Johnson, I., Sorokin, N. (2004). Proposed PredictedNo-Effect-Concentrations (PNECs) for Natural and Synthetic Steroid Oestrogens in Surface Waters. Environmental Agency Bristol, R\&D Technical Report P2-T04/1.

\section{Copyrights}

Copyright for this article is retained by the author(s), with first publication rights granted to the journal.

This is an open-access article distributed under the terms and conditions of the Creative Commons Attribution license (http://creativecommons.org/licenses/by/4.0/) 